\section{Crop Injury from Sublethal Rates of Herbicide. I. Tomato}

\author{
James P. Gilreath ${ }^{1}$ \\ Gulf Coast Research and Education Center, University of Florida, \\ Bradenton, FL 34203
}

\section{Carlene A. Chase and Salvadore J. Locascio \\ Horticultural Sciences Department, University of Florida, Gainesville, FL 32611-0690}

Additional index words. spray drift, herbicide injury, flower abscission, Lycopersicon esculentum

\begin{abstract}
Drift from pesticides can kill or damage nontarget organisms. In these studies, the effects of sublethal rates of the herbicide glyphosate applied prebloom, at bloom, and postbloom of the first flower cluster were evaluated in tomato (Lycopersicon esculentum Mill.). As rates increased from 1 to $100 \mathrm{~g} \cdot \mathrm{ha}^{-1}$, foliar injury and flower and fruit number per plant varied with the stage of development at the time of exposure and the time of evaluation after treatment. Plants treated with 60 and $100 \mathrm{~g} \cdot \mathrm{ha}^{-1}$ glyphosate prebloom and at bloom had developed moderate to severe foliar injury by 14 days after treatment, but phytotoxicity to plants treated postbloom was only mild to moderate. Blooms abscised from plants treated with 60 and $100 \mathrm{~g} \cdot \mathrm{ha}^{-1}$ glyphosate for several weeks after application and fruit set was reduced. Greatest yield losses occurred following treatment prebloom (just prior to bloom) and at bloom. Plants treated before emergence of flower buds, and more mature plants exposed when first cluster fruit were sizing, yielded better than did those treated just prior to bloom and at bloom. Chemical name used: $N$-(phosphonomethyl)glycine (glyphosate).
\end{abstract}

Spray drift of glyphosate presents a potential problem to nontarget crops. Injury due to drift tends to be more extensive and persistent with glyphosate than with other herbicides (Atkinson, 1985). With the advent of glyphosate-resistant crops, the use of glyphosate is expected to increase considerably, with accompanying increased risks of injury to nontarget plants. The potential for glyphosate drift varies with application methods; it is greater with aerial than with ground application (Yates et al., 1978). Inclusion of a thickening agent provides some drift reduction during application with ground equipment and fixed-wing aircraft. Mueller and Womac (1997) advocate the reduction of glyphosate spray drift by minimizing the proportion of small droplets with appropriate selection of nozzle type, formulation, and operating pressure. An assay for the rapid diagnosis of glyphosate injury has been developed by Singh and Shaner (1998).

Translocated primarily in the phloem, glyphosate tends to accumulate in the meristematic regions. Russo (1990) reported that an accidental, sublethal exposure of tomato plants to glyphosate drift during the vegetative growth phase resulted in chlorosis of the ter-

Received for publication 2 Mar. 2000. Accepted for publication 14 Aug. 2000. Florida Agricultural Experiment Station Journal Series No. R-07643. The cost of publishing this paper was defrayed in part by the payment of page charges. Under postal regulations, this paper therefore must be hereby marked advertisement solely to indicate this fact.

${ }^{1}$ To whom requests for reprints should be addressed. E-mail address: DrGilreath@aol.com minal bud and the youngest foliage. At the cellular level, sublethal glyphosate treatment caused swelling of proplastids in tomato shoot apices (Mollenhauer et al., 1987). In the apical region, chloroplast swelling was observed in young leaves that had vascular connections, leading to loss of structural integrity. Mollenhauer et al. (1987) proposed that the apical meristem is protected from injury because there are no direct connections to the vascular bundles, and recovery occurs as a result of rapid cell division.

Semidey and Amodóver (1987) reported that directed sprays of glyphosate provided more effective weed control than did handweeding, but tomato yields were significantly lower with the glyphosate treatment. There were no visible signs of injury on the plants, and glyphosate exposure was thought to have occurred through uptake from the soil. Although glyphosate is generally regarded to be nonresidual and inactive in soil, residues that were phytotoxic to tomatoes have been reported in sandy loam soils with $>80 \%$ sand (Cornish, 1992; Eberbach and Douglas, 1983). Following simulated glyphosate drift on processing tomatoes, foliar chlorosis, interrupted growth of leaves, and abnormal fruit development were observed (Romanowski, 1980). A rate of $100 \mathrm{~g} \cdot \mathrm{ha}^{-1}$ glyphosate reduced tomato yields when applied early and mid-season, but not when applied late in the season. In Florida, the tomato crop is exclusively fresh market; thus the quality and the size of the fruit are of greater importance than for processing tomato. The effect of glyphosate drift has not been previously assessed on fresh-market to- mato and we wished to evaluate whether glyphosate rates of $<100 \mathrm{~g} \cdot \mathrm{ha}^{-1}$ were potentially hazardous to tomato crops. The objectives of these studies were to evaluate the extent of phytotoxic injury and the effect on yield of fresh market tomato exposed at three stages of development to levels of glyphosate known to be sublethal.

\section{Materials and Methods}

Three field studies were conducted at Bradenton, Fla., in Spring and Fall 1988 and Spring 1989, on an EauGallie fine sand (sandy, siliceous, hyperthermic, Alfic Haplaquod). In the factorial experiments, varying sublethal rates of glyphosate (Roundup 4EC ${ }^{\circledR}$; Monsanto Agricultural Products, St. Louis) were applied at three reproductive growth stages of 'Sunny' tomato. The active ingredient was applied at 0 , 1,10 , and $100 \mathrm{~g} \cdot \mathrm{ha}^{-1}$ in a volume of $234 \mathrm{~L}$ with a $\mathrm{CO}_{2}$ backpack sprayer equipped with a single 11005 flat-fan nozzle tip. The pressure was 76 $\mathrm{kPa}$ in Expt. 1, $80 \mathrm{kPa}$ in Expt. 2, and 83 to 97 $\mathrm{kPa}$ in Expt. 3. Treatments were arranged in a randomized complete-block design with five replications in Spring 1988, and six replications in the other studies.

Staked fresh market tomatoes were grown on $15-\mathrm{cm}$, polyethylene-mulched, raised beds using subsurface irrigation. Soil was fumigated with a 67 methyl bromide : 33 chloropicrin (trichloronitromethane) mixture (392 $\left.\mathrm{kg} \cdot \mathrm{ha}^{-1}\right)$. Two bands of fertilizer, supplying 60,0 and $84 \mathrm{~kg} \cdot \mathrm{ha}^{-1}$ of $\mathrm{N}, \mathrm{P}$, and $\mathrm{K}$, respectively, were applied on the bed surface just prior to covering the bed with polyethylene film mulch. Single row plots were separated from one another by an adjacent unplanted row on each side and an alley at each end. In Expt. 1, interplant spacing was $0.46 \mathrm{~m}$ on 0.76 $\mathrm{m}$-wide beds. Plots were $6.1 \mathrm{~m}$ long $\times 1.37 \mathrm{~m}$ wide, and the alley between plots was $2.44 \mathrm{~m}$ long. In Expt. 2, plot sizes $(7.62 \times 1.52 \mathrm{~m})$ were slightly larger. Plants were spaced 0.61 $\mathrm{m}$ apart on $0.81-\mathrm{m}$-wide beds, with a $1.52-\mathrm{m}-$ long unplanted alley between plots. In Expt. 3 , plots were $6.1 \times 1.52 \mathrm{~m}$. Interplant spacing and bed width were the same as in Expt. 2, leaving a 1.22-m-long alley between plots.

In Expt. 1, tomato plants were transplanted on 23 Feb. 1988. Glyphosate was applied at the following stages of development: prebloom (21 Mar.); at bloom, first cluster blooms open (29 Mar.); and postbloom, when fruits on the first cluster were $4 \mathrm{~cm}$ in diameter (15 Apr.).

In Expt. 2, tomatoes were transplanted on 13 Sept. 1988. Glyphosate was applied prebloom (10 Oct.), at bloom (21 Oct.), and postbloom, when fruits on the first cluster were 4.4 to $5 \mathrm{~cm}$ in diameter (7 Nov.). The herbicide rates were the same as in Expt. 1. In Expt. 3, tomatoes were transplanted on $17 \mathrm{Feb}$. 1989. Two additional glyphosate rates were included and the herbicide was applied at 0,1 , 6, 10, 60, and $100 \mathrm{~g} \cdot \mathrm{ha}^{-1}$ on 8 Mar., $25 \mathrm{Mar}$., and 5 Apr., respectively. Glyphosate was applied prebloom (3 weeks after transplanting), at bloom, and postbloom (first cluster fruit $2.5-3.8 \mathrm{~cm}$ in diameter).

Data collection and analysis. Plants were 
rated for injury and the number of open flowers and fruits were counted 7, 14, 21, and $28 \mathrm{~d}$ after treatment (DAT). Buds and senescing flowers were not counted. In Expt. 1, data for numbers of blooms and fruits were collected for glyphosate treatments applied at prebloom and bloom stages of development only. Foliar injury (foliar chlorosis and leaf distortion) was evaluated visually on a scale of 0 to 10 (Frans et al., 1986). A rating of 0 indicated no injury and 10 indicated that $100 \%$ of the tissue was affected. A phytotoxicity rating of 1 to 3 was slight, 4 to 6 was moderate, and ratings above 7 were considered to be severe. Fruit were harvested on 26 May, 6 June, and 18 June 1988 (Expt. 1); 14 Dec. (first color showing) and 20 Dec. 1988 (mature green stage in anticipation of a freeze) (Expt. 2); and 15, 24, 31 May, and 8 June 1989 (Expt. 3). Fruit were sorted into three marketable sizes (extra large, large, medium) and culls. Tests for significance for the main effects of herbicide rate, stage of growth, and their interactions were conducted using analysis of variance. The nature of significant responses to glyphosate rate and the effect of time of evaluation were assessed using orthogonal polynomials. When needed, a logarithmic transformation was performed on yield variables prior to analysis to adjust for heterogeneity of variances (Snedecor and Cochran, 1980). Means for yield are presented as nontransformed data.

\section{Results}

Foliar injury. Phytotoxicity was characterized by chlorosis and upward curling of leaves. Plant height was also reduced, as reported by Gilreath et al. (2000). Foliar injury was generally mild with glyphosate rates $\leq 10 \mathrm{~g} \cdot \mathrm{ha}^{-1}$; however, interaction among glyphosate rate, stage of development at application, and time of evaluation after treatment was significant in all three experiments $(P \leq 0.0001)$. In Expts. 1 and 2, phytotoxicity increased with glyphosate rate (Table 1), but the extent to which injury occurred with prebloom and bloom applications differed with time $(P \leq 0.0001)$. Severe foliar injury was apparent as early as 7 DAT following prebloom applications of $100 \mathrm{~g} \cdot \mathrm{ha}^{-1}$ and 14 DAT following bloom applications in Expt. 1. In Expt. 2, foliar injury was moderate within $7 \mathrm{~d}$ of prebloom and bloom applications. Severe injury symptoms had developed by $14 \mathrm{~d}$ after prebloom applications and $28 \mathrm{~d}$ after bloom applications of $100 \mathrm{~g} \cdot \mathrm{ha}^{-1}$ glyphosate. With postbloom application, phytotoxicity was mild with rates of $\leq 10 \mathrm{~g} \cdot \mathrm{ha}^{-1}$ and moderate with $100 \mathrm{~g} \cdot \mathrm{ha}^{-1}$. In Expt. 1, foliar injury with postbloom applications remained constant over 4 weeks of evaluations. In Expt. 2, time of evaluation was significant $(P \leq 0.002)$, with phytotoxicity increasing marginally from 1 at 7 DAT to 1.5 at 14 DAT, with no further increases at subsequent evaluations (data not shown).

In Expt. 3, interaction between rate and time of evaluation was significant for all three stages of development $(P \leq 0.0001)$, indicating that the increase in foliar injury with increases in rate varied with the stage of development at application. Applications of 60 and $100 \mathrm{~g} \cdot \mathrm{ha}^{-1}$ glyphosate at all stages of development caused mild phytotoxicity within $7 \mathrm{~d}$ (Table 1). By $14 \mathrm{~d}$ after prebloom and bloom applications and at subsequent evaluations, foliar injury was severe with 60 and 100 $\mathrm{g} \cdot \mathrm{ha}^{-1}$ glyphosate. Although phytotoxicity increased with increasing rates applied postbloom, foliar injury was mild to moderate with 60 and $100 \mathrm{~g} \cdot \mathrm{ha}^{-1}$ glyphosate.
Number of flowers. Flower number increased over time due to the progression of reproductive development. Flower number peaked during the $21 \mathrm{~d}$ following bloom (Expts. 1 and 2) and postbloom applications (Expts. 2 and 3), then subsequently declined (Table 2). Since this reduction in flower number also occurred in nontreated plants and care was taken to avoid drift when glyphosate was applied, the decline in flower number over time could be attributed to fruit set and flower abscission because of environmental factors or lack of pollination. However, reductions in flower number with 60 to $100 \mathrm{~g} \cdot \mathrm{ha}^{-1}$ glyphosate were due primarily to flower abscission and persisted for several weeks after treatment.

Glyphosate rate, stage of application, and time of evaluation interacted in affecting flower number in all three experiments $(P \leq 0.01)$. In Expt. 1, glyphosate rate did not affect flower number $7 \mathrm{~d}$ after prebloom application. However, by 14 DAT, decline in flower number was linear as rates of glyphosate increased from 0 to $100 \mathrm{~g} \cdot \mathrm{ha}^{-1}$. The $100 \mathrm{~g} \cdot \mathrm{ha}^{-1}$ rate promoted extensive flower abscission so that no flowers were retained during the $28 \mathrm{~d}$ following prebloom application. At all evaluation times following bloom applications, flower number declined linearly as glyphosate rate increased; however, the rate of decrease differed with time after treatment $(P \leq 0.001)$.

In Expt. 2, the effect of rate differed with evaluation date when glyphosate was applied prebloom and at bloom $(P \leq 0.001)$; however, no interaction occurred with postbloom application and data were pooled over evaluation times (Table 2). No significant difference in flower number occurred within $7 \mathrm{~d}$ of prebloom or bloom applications. However, by 14 DAT, flower number in plants treated with $100 \mathrm{~g} \cdot \mathrm{ha}^{-1}$ had significantly declined. Aver-

Table 1. Effects of sublethal rates of glyphosate and stage of development on foliar injury ${ }^{z}$.

\begin{tabular}{|c|c|c|c|c|c|c|c|c|c|c|c|c|c|c|c|c|}
\hline \multirow{3}{*}{$\begin{array}{l}\text { Rate } \\
\left(\mathrm{g} \cdot \mathrm{ha}^{-1}\right)\end{array}$} & \multirow[b]{3}{*}{$\mathrm{DAT}^{\mathrm{y}}$ : } & \multicolumn{15}{|c|}{ Time of treatment } \\
\hline & & \multicolumn{5}{|c|}{ Prebloom } & \multicolumn{5}{|c|}{ Bloom } & \multicolumn{5}{|c|}{ Postbloom } \\
\hline & & 7 & 14 & 21 & 28 & Sig. & 7 & 14 & 21 & 28 & Sig. & 7 & 14 & 21 & 28 & Sig. \\
\hline \multicolumn{17}{|c|}{ Expt. 1} \\
\hline 0 & & 0.0 & 0.0 & 0.0 & 0.0 & --- & 0.0 & 0.0 & 0.0 & 0.0 & --- & \multicolumn{5}{|c|}{$0.0^{x}$} \\
\hline 1 & & 0.0 & 0.0 & 0.0 & 0.1 & NS & 0.1 & 0.6 & 0.5 & 0.7 & NS & \multicolumn{5}{|c|}{0.5} \\
\hline 10 & & 1.4 & 5.0 & 3.4 & 2.9 & $\mathrm{Q}^{* *}$ & 0.3 & 1.1 & 0.9 & 0.8 & NS & \multicolumn{5}{|c|}{1.2} \\
\hline 100 & & 7.9 & 8.6 & 8.2 & 10.0 & $\mathrm{Q}^{* *}$ & 4.5 & 7.4 & 8.0 & 8.1 & $\mathrm{Q}^{* *}$ & \multicolumn{5}{|c|}{3.8} \\
\hline Significance & & $\mathrm{Q}^{* *}$ & $\mathrm{Q}^{* *}$ & $\mathrm{Q}^{* *}$ & $\mathrm{Q}^{* *}$ & & $\mathrm{~L}^{* *}$ & $\mathrm{~L}^{* *}$ & $\mathrm{~L}^{* *}$ & $\mathrm{~L}^{* *}$ & & \multicolumn{5}{|c|}{$\mathrm{Q}^{* *}$} \\
\hline \multicolumn{17}{|c|}{ Expt. 2} \\
\hline 0 & & 0.0 & 0.0 & 0.0 & 0.0 & --- & 0.0 & 0.0 & 0.0 & 0.0 & --- & \multicolumn{5}{|c|}{0.0} \\
\hline 1 & & 0.2 & 0.2 & 0.3 & 1.3 & $\mathrm{Q}^{* *}$ & 0.1 & 0.3 & 0.8 & 1.1 & $\mathrm{~L}^{* *}$ & \multicolumn{5}{|c|}{1.1} \\
\hline 10 & & 0.5 & 1.9 & 2.1 & 2.7 & $\mathrm{Q}^{* *}$ & 0.7 & 0.6 & 0.9 & 1.4 & NS & \multicolumn{5}{|c|}{1.6} \\
\hline 100 & & 3.5 & 7.2 & 7.8 & 8.9 & $\mathrm{Q}^{* *}$ & 3.3 & 4.1 & 5.3 & 7.4 & $\mathrm{Q}^{* *}$ & \multicolumn{5}{|c|}{2.9} \\
\hline Significance & & $\mathrm{L}^{* *}$ & $\mathrm{Q}^{* *}$ & $\mathrm{Q}^{* *}$ & $\mathrm{Q}^{* *}$ & & $\mathrm{~L}^{* *}$ & $\mathrm{~L}^{* *}$ & $\mathrm{~L}^{* *}$ & $\mathrm{~L}^{* *}$ & & \multicolumn{5}{|c|}{$\mathrm{Q}^{* *}$} \\
\hline \multicolumn{17}{|c|}{ Expt. 3} \\
\hline 0 & & 0.0 & 0.0 & 0.0 & 0.0 & --- & 0.0 & 0.0 & 0.0 & 0.1 & NS & 0.0 & 0.0 & 0.0 & 0.0 & --- \\
\hline 1 & & 0.0 & 0.3 & 0.4 & 0.3 & $\mathrm{Q}^{* *}$ & 0.3 & 0.3 & 0.7 & 0.5 & NS & 0.1 & 0.4 & 0.4 & 0.3 & NS \\
\hline 6 & & 0.0 & 0.3 & 0.4 & 0.8 & $\mathrm{~L}^{* * *}$ & 0.0 & 0.1 & 0.3 & 0.9 & $\mathrm{Q}^{* *}$ & 0.1 & 0.5 & 0.3 & 0.4 & NS \\
\hline 10 & & 0.3 & 1.4 & 1.2 & 0.9 & $\mathrm{Q}^{* *}$ & 0.2 & 0.7 & 1.6 & 1.8 & $\mathrm{~L}^{* *}$ & 0.1 & 1.0 & 0.8 & 0.8 & $\mathrm{Q}^{* *}$ \\
\hline 60 & & 1.8 & 7.6 & 8.2 & 8.1 & $\mathrm{Q}^{* *}$ & 1.5 & 7.6 & 8.0 & 7.8 & $\mathrm{Q}^{* *}$ & 1.3 & 2.3 & 3.4 & 3.9 & $\mathrm{~L}^{* *}$ \\
\hline 100 & & 2.6 & 8.6 & 9.2 & 9.3 & $\mathrm{Q}^{* *}$ & 2.1 & 7.7 & 8.0 & 8.7 & $\mathrm{Q}^{* *}$ & 1.8 & 3.1 & 4.4 & 4.2 & $\mathrm{~L}^{* *}$ \\
\hline Significance & & $\mathrm{L}^{* * *}$ & $\mathrm{Q}^{* *}$ & $\mathrm{Q}^{* *}$ & $\mathrm{Q}^{* *}$ & & $\mathrm{~L}^{* * *}$ & $\mathrm{Q}^{* * *}$ & $\mathrm{Q}^{* *}$ & $\mathrm{Q}^{* * *}$ & & $\mathrm{~L}^{* *}$ & $\mathrm{Q}^{* *}$ & $\mathrm{Q}^{* *}$ & $\mathrm{Q}^{* *}$ & \\
\hline
\end{tabular}

${ }^{2}$ Phytotoxicity was measured on a scale of 0 (no injury) to 10 (100\% foliar chlorosis).

${ }^{\mathrm{y}}$ Days after treatment.

xPhytotoxicity averaged over all evaluation times.

**:Linear (L) and quadratic (Q) effects significant at $P \leq 0.01$. 
Table 2. Effects of sublethal rates of glyphosate and stage of development on flower number per plant.

\begin{tabular}{|c|c|c|c|c|c|c|c|c|c|c|c|c|c|c|c|c|}
\hline \multirow{3}{*}{$\begin{array}{l}\text { Rate } \\
\left(\mathrm{g} \cdot \mathrm{ha}^{-1}\right) \\
\end{array}$} & \multirow[b]{3}{*}{ DAT $^{\mathrm{z}}$ : } & \multicolumn{15}{|c|}{ Time of treatment } \\
\hline & & \multicolumn{5}{|c|}{ Prebloom } & \multicolumn{5}{|c|}{ Bloom } & \multicolumn{5}{|c|}{ Postbloom } \\
\hline & & 7 & 14 & 21 & 28 & Sig. & 7 & 14 & 21 & 28 & Sig. & 7 & 14 & 21 & 28 & Sig. \\
\hline \multicolumn{17}{|c|}{ Expt. 1} \\
\hline 0 & & 2 & 35 & 67 & 84 & $\mathrm{~L}^{* *}$ & 40 & 70 & 82 & 44 & $\mathrm{Q}^{* *}$ & $---y^{y}$ & --- & --- & --- & \\
\hline 1 & & 3 & 30 & 63 & 84 & $\mathrm{~L}^{* *}$ & 30 & 67 & 77 & 50 & $\mathrm{Q}^{* *}$ & --- & --- & --- & --- & \\
\hline 10 & & 3 & 26 & 57 & 88 & $\mathrm{~L}^{* *}$ & 30 & 64 & 61 & 46 & $\mathrm{Q}^{* *}$ & --- & --- & --- & --- & \\
\hline 100 & & 3 & 0 & 0 & 0 & $\mathrm{Q}^{* *}$ & 19 & 19 & 8 & 5 & $\mathrm{~L}^{* *}$ & --- & --- & --- & --- & \\
\hline Significance & & NS & $\mathrm{L}^{* *}$ & $\mathrm{~L}^{* *}$ & $\mathrm{Q}^{*}$ & & $\mathrm{~L}^{*}$ & $\mathrm{~L}^{* *}$ & $\mathrm{~L}^{* *}$ & $\mathrm{~L}^{* *}$ & & & & & & \\
\hline \multicolumn{17}{|c|}{ Expt. 2} \\
\hline 0 & & 20 & 49 & 73 & 89 & $\mathrm{~L}^{* *}$ & 43 & 100 & 61 & 68 & $\mathrm{C}^{* *}$ & \multicolumn{5}{|c|}{$50^{x}$} \\
\hline 1 & & 23 & 54 & 64 & 88 & $\mathrm{~L}^{* *}$ & 52 & 107 & 76 & 82 & $\mathrm{C}^{* *}$ & \multicolumn{5}{|c|}{53} \\
\hline 10 & & 22 & 54 & 88 & 84 & $\mathrm{~L}^{* *}$ & 59 & 109 & 76 & 92 & $\mathrm{C}^{* *}$ & \multicolumn{5}{|c|}{46} \\
\hline 100 & & 15 & 26 & 14 & 15 & $\mathrm{C}^{* *}$ & 40 & 68 & 28 & 9 & $\mathrm{Q}^{* *}$ & \multicolumn{5}{|c|}{35} \\
\hline Significance & & NS & $\mathrm{L}^{* *}$ & $\mathrm{Q}^{* *}$ & $\mathrm{~L}^{* *}$ & & NS & $\mathrm{L}^{* *}$ & $\mathrm{~L}^{* *}$ & $\mathrm{Q}^{* *}$ & & \multicolumn{5}{|c|}{$\mathrm{L}^{* *}$} \\
\hline \multicolumn{17}{|c|}{ Expt. 3} \\
\hline 0 & & $---w$ & 2 & 5 & 20 & $\mathrm{~L}^{* *}$ & 7 & 26 & 34 & 50 & $\mathrm{~L}^{* *}$ & 32 & 52 & 39 & 19 & $\mathrm{Q}^{* *}$ \\
\hline 1 & & --- & 2 & 4 & 21 & $\mathrm{~L}^{* *}$ & 8 & 27 & 32 & 40 & $\mathrm{Q}^{* *}$ & 33 & 47 & 42 & 20 & $\mathrm{Q}^{* *}$ \\
\hline 6 & & --- & 2 & 4 & 17 & $\mathrm{~L}^{* *}$ & 7 & 24 & 39 & 42 & $\mathrm{Q}^{* *}$ & 33 & 49 & 46 & 17 & $\mathrm{Q}^{* *}$ \\
\hline 10 & & --- & 1 & 3 & 16 & $\mathrm{~L}^{* *}$ & 8 & 30 & 55 & 38 & $\mathrm{Q}^{* *}$ & 31 & 45 & 41 & 18 & $\mathrm{Q}^{* *}$ \\
\hline 60 & & --- & 1 & 1 & 1 & NS & 5 & 17 & 19 & 15 & $\mathrm{Q}^{* *}$ & 35 & 45 & 23 & 7 & $\mathrm{Q}^{* *}$ \\
\hline 100 & & --- & 0 & 0 & 0 & --- & 6 & 10 & 8 & 3 & $\mathrm{Q}^{* *}$ & 26 & 29 & 8 & 8 & $\mathrm{~L}^{* *}$ \\
\hline Significance & & NS & NS & $\mathrm{L}^{* *}$ & $\mathrm{Q}^{* *}$ & & NS & $\mathrm{L}^{* *}$ & $\mathrm{~L}^{* *}$ & $\mathrm{~L}^{* *}$ & & NS & $\mathrm{L}^{* *}$ & $\mathrm{~L}^{* *}$ & $\mathrm{~L}^{* *}$ & \\
\hline
\end{tabular}

${ }^{2}$ Days after treatment.

${ }^{y}$ No data collected for postbloom applications in Expt. 1.

${ }^{x}$ Flower number averaged over all evaluation times.

${ }^{\mathrm{w}}$ No flowers formed at this stage.

ss, *,** Nonsignificant and significant at $P \leq 0.05$ and $P \leq 0.01$, respectively, for linear (L) and quadratic (Q) effects.

aged over evaluation dates, postbloom applications of glyphosate reduced flower number linearly, with a maximum reduction (15 flowers) at $100 \mathrm{~g} \cdot \mathrm{ha}^{-1}$. During the $28 \mathrm{~d}$ following postbloom application, a quadratic decline in flower number per plant occurred from 112 at 7 DAT to 3 at 28 DAT $(P \leq 0.0001$, data not shown).

In Expt. 3, prebloom treatments were applied before flowers appeared. Differences in flower number were nonsignificant until 21 DAT, when flower number decreased linearly with glyphosate rate (Table 2). By 28 DAT, flower numbers with 60 and $100 \mathrm{~g} \cdot \mathrm{ha}^{-1}$ were 1 and 0 , respectively vs. 20 flowers per nontreated plant. Whereas, no change in flower number had occurred by $7 \mathrm{~d}$ after bloom and postbloom treatments, the decline in flower number was linear at all subsequent times of evaluation.

Number of fruit. In Expts. 1 and 3, the response of fruit number to increasing glyphosate rate differed with stage of development and time of evaluation (interaction significant at $P \leq 0.001$ ). In Expt. 1, for applications at prebloom and bloom stages, interaction between rate and time of evaluation was also significant $(P \leq 0.0001)$. No fruit were present $7 \mathrm{~d}$ after prebloom applications and two or fewer fruits per plant were observed 14 DAT, with no significant response to herbicide rate (Table 3 ). At 21 and 28 DAT, significantly fewer fruit were set by plants treated with $10 \mathrm{~g} \cdot \mathrm{ha}^{-1} \mathrm{glyphosate}$ and no fruit were set with the $100 \mathrm{~g} \cdot \mathrm{ha}^{-1}$ rate. Fruit number increased linearly over time following prebloom glyphosate applications of 0 to $10 \mathrm{~g} \cdot \mathrm{ha}^{-1}$, but no fruit set on plants treated with $100 \mathrm{~g} \cdot \mathrm{ha}^{-1}$ glyphosate. Fruit set increased with time regardless of treatment when applied at bloom.

In Expt. 2, the interaction between rate and stage of development did not change with time after treatment; therefore, data for fruit number for each stage were pooled across evaluation times. Fruit number declined linearly with increasing rates of glyphosate applied prebloom and at bloom, and a quadratic decrease in fruit number occurred with postbloom application (Table 3). Fruit number was reduced $15 \%$ and $80 \%$ following prebloom application of 10 and $100 \mathrm{~g} \cdot \mathrm{ha}^{-1}$, respectively. Bloom application of $100 \mathrm{~g} \cdot \mathrm{ha}^{-1}$ reduced fruit number by $40 \%$, but the $10 \mathrm{~g} \cdot \mathrm{ha}^{-1}$ rate had no effect. Postbloom applications of 10 and 100 $\mathrm{g} \cdot \mathrm{ha}^{-1}$ reduced fruit number $10 \%$.

In Expt. 3, the delay in flowering when glyphosate was applied at the prebloom stage caused a concomitant delay in fruit set, so that the first fruits were noted at $28 \mathrm{DAT}$ (Table 3 ). There were $<10$ fruits per plant and fruit number decreased to zero with glyphosate rates of 60 and $100 \mathrm{~g} \cdot \mathrm{ha}^{-1}$. Although no difference in fruit number was observed within $14 \mathrm{~d}$ of bloom applications, reductions in fruit number were apparent at 21 and 28 DAT. The decline with bloom applications of glyphosate at 21 DAT was linear, with reductions in fruit number of $20 \%, 40 \%$, and $80 \%$ at rates of 10 , 60 , and $100 \mathrm{~g} \cdot \mathrm{ha}^{-1}$ glyphosate, respectively. By 28 DAT, the decline in fruit number was quadratic with $44 \%, 77 \%$, and $87 \%$ reductions at the same rates.

With postbloom applications of glyphosate, there was no interaction between rate and time after treatment. Averaged over time of evaluation, fruit number declined linearly as glyphosate rates increased (Table 3 ). Fruit number was reduced by $8 \%$ with $60 \mathrm{~g} \cdot \mathrm{ha}^{-1}$ and by $24 \%$ with $100 \mathrm{~g} \cdot \mathrm{ha}^{-1}$ glyphosate. Averaged over all rates, there were 13 fruits per plant $7 \mathrm{~d}$ after postbloom application, and this increased quadratically over time to 68 fruits per plant at $28 \mathrm{DAT}(P \leq 0.0001$, data not shown).
Yield. The effect of glyphosate on tomato yield was dependent upon the stage of development when the herbicide was applied (interaction significant at $P \leq 0.05$ ). Stage of development did not affect yield when glyphosate was applied at $1 \mathrm{~g} \cdot \mathrm{ha}^{-1}$ in any of the experiments (Table 4). Some significant changes in yield occurred with $10 \mathrm{~g} \cdot \mathrm{ha}^{-1}$ (Expts. 1 and 2), but yield was affected primarily by the 60 and $100 \mathrm{~g} \cdot \mathrm{ha}^{-1}$ rates. The yields of extra large and cull fruit declined linearly in Expt. 1 with increasing rates of glyphosate applied prebloom and at bloom, but were unaffected when glyphosate was applied postbloom. Yields of large fruit decreased linearly as rate increased when plants were treated at all stages of development. With prebloom glyphosate applications, reductions in yields of medium and marketable tomatoes were quadratic, whereas reductions following bloom and postbloom applications were linear. Yields of extra large, marketable, and cull fruits by plants treated prebloom with $10 \mathrm{~g} \cdot \mathrm{ha}^{-1}$ glyphosate were lower than those of plants treated at bloom and postbloom, which were statistically similar. All categories of fruit yield with $100 \mathrm{~g} \cdot \mathrm{ha}^{-1}$ glyphosate were similar with prebloom and bloom applications, but were significantly lower than yields obtained with postbloom applications. Marketable yield was $67 \mathrm{t} \cdot \mathrm{ha}^{-1}$ with postbloom application of $100 \mathrm{~g} \cdot \mathrm{ha}^{-1}$ vs. $<3 \mathrm{t} \cdot \mathrm{ha}^{-1}$ with application at earlier stages of development.

With prebloom or bloom applications in Expt. 2, yields of all marketable fruit sizes and total marketable fruit yield decreased as glyphosate rate increased to $100 \mathrm{~g} \cdot \mathrm{ha}^{-1}$. However, except for a decrease in medium-sized tomatoes, glyphosate did not reduce yield significantly when applied postbloom. Only the yield of the medium-sized fruit was affected by stage of development when glyphosate was 
applied at $10 \mathrm{~g} \cdot \mathrm{ha}^{-1}$. Yields were lowest with the prebloom treatment, intermediate with bloom treatment, and highest with the postbloom application. As in Expt. 1, prebloom and bloom applications of $100 \mathrm{~g} \cdot \mathrm{ha}^{-1}$ glyphosate resulted in similar yields of extra lower than corresponding yields with postbloom application. However, total marketable yield following bloom application of $100 \mathrm{~g} \cdot \mathrm{ha}^{-1}$ glyphosate was $9 \mathrm{t} \cdot \mathrm{ha}^{-1}$, greater than the $0.3 \mathrm{t} \cdot \mathrm{ha}^{-1}$ obtained following prebloom application. Marketable yield $\left(54 \mathrm{t} \cdot \mathrm{ha}^{-1}\right)$ with $100 \mathrm{~g} \cdot \mathrm{ha}^{-1}$ was highest with postbloom application. Only prebloom application of large, large, and medium fruit, which were

$100 \mathrm{~g} \cdot \mathrm{ha}^{-1}$ glyphosate reduced the yield of cull fruits.

In Expt. 3, the yield of all categories of marketable fruit decreased with increasing rates of glyphosate; however, the rate of decline differed with stage of development $(P \leq$ 0.0001 ). Analysis of the main effects revealed that stage of development had no effect on yield at rates $\leq 10 \mathrm{~g} \cdot \mathrm{ha}^{-1}$. Yields of extra large and large fruit following prebloom and postbloom applications of glyphosate were similar, and were higher than yields obtained with bloom application. Prebloom applications of 60 and $100 \mathrm{~g} \cdot \mathrm{ha}^{-1}$ glyphosate resulted in the highest yields of large fruit and total

Table 3. Effects of sublethal rates of glyphosate and stage of development on fruit number per plant.

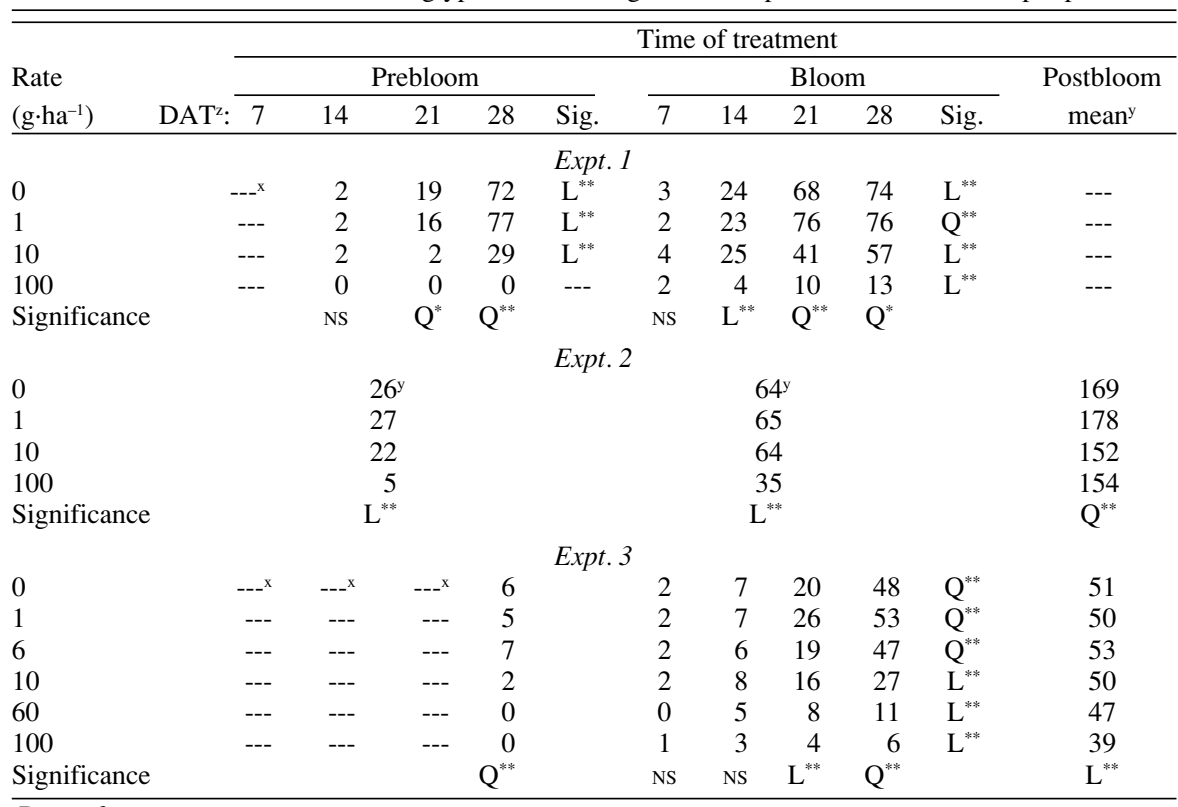

${ }^{2}$ Days after treatment.

${ }^{y}$ Fruit number averaged over all evaluation times.

${ }^{x}$ No fruit formed at this stage.

${ }_{\text {Ns, }, * * *}$ Nonsignificant and significant at $P \leq 0.05$ and $P \leq 0.01$, respectively, for linear (L) and quadratic (Q) effects.

Table 4. Effects of sublethal rates of glyphosate applied prebloom (preblm), at bloom (blm), and postbloom (pstblm) on yield of extra large, large, medium, total marketable, and cull tomato fruit $\left(\mathrm{t} \cdot \mathrm{ha}^{-1}\right)$.

\begin{tabular}{|c|c|c|c|c|c|c|c|c|c|c|c|c|c|c|c|}
\hline \multirow{2}{*}{$\begin{array}{l}\text { Rate } \\
\left(\mathrm{g} \cdot \mathrm{ha}^{-1}\right)\end{array}$} & \multicolumn{3}{|c|}{ Extra large } & \multicolumn{3}{|c|}{ Large } & \multicolumn{3}{|c|}{ Medium } & \multicolumn{3}{|c|}{ Marketable } & \multicolumn{3}{|c|}{ Cull } \\
\hline & Preblm & Blm & Pstblm & Preblm & $\mathrm{B} 1 \mathrm{~m}$ & Pstblm & Preblm & $\mathrm{B} \operatorname{lm}$ & Pstblm & Preblm & Blm & Pstblm & Preblm & Blm & Pstblm \\
\hline \multicolumn{16}{|c|}{ Expt. 1} \\
\hline 0 & 49.7 & 62.5 & 55.0 & 40.8 & 41.3 & 43.8 & 24.6 & 17.8 & 24.2 & 115.1 & 121.6 & 123.0 & 51.2 & 60.2 & 55.1 \\
\hline 10 & $13.1 \mathrm{~b}^{\mathrm{z}}$ & $48.9 \mathrm{a}$ & $56.3 \mathrm{a}$ & 34.9 & 44.6 & 39.8 & 26.7 & 21.3 & 18.3 & $74.7 \mathrm{~b}$ & $114.8 \mathrm{a}$ & $114.4 \mathrm{a}$ & $48.7 \mathrm{~b}$ & $64.3 \mathrm{a}$ & $63.1 \mathrm{a}$ \\
\hline 100 & $0.1 \mathrm{~b}$ & $0.1 \mathrm{~b}$ & $36.9 \mathrm{a}$ & $0.8 \mathrm{~b}$ & $0.3 \mathrm{~b}$ & $21.3 \mathrm{a}$ & $1.5 \mathrm{~b}$ & $0.7 \mathrm{~b}$ & $8.5 \mathrm{a}$ & $2.3 \mathrm{a}$ & $1.1 \mathrm{a}$ & $66.7 \mathrm{a}$ & $11.1 \mathrm{~b}$ & $11.1 \mathrm{~b}$ & $67.4 \mathrm{a}$ \\
\hline Sig. & $\mathrm{L}^{* * *}$ & $\mathrm{~L}^{* *}$ & NS & $\mathrm{L}^{* *}$ & $\mathrm{~L}^{* * *}$ & $\mathrm{~L}^{* *}$ & $\mathrm{Q}^{*}$ & $\mathrm{~L}^{* *}$ & $\mathrm{~L}^{* *}$ & $\mathrm{Q}^{* *}$ & $\mathrm{~L}^{* *}$ & $\mathrm{~L}^{* *}$ & $\mathrm{~L}^{* *}$ & $\mathrm{~L}^{* *}$ & NS \\
\hline \multicolumn{16}{|c|}{ Expt. 2} \\
\hline 1 & 11.4 & 8.5 & 14.8 & 21.2 & 16.7 & 23.1 & 26.0 & 25.7 & 28.7 & 58.7 & 51.0 & 66.6 & 26.9 & 29.8 & 26.4 \\
\hline 10 & 11.2 & 14.3 & 11.2 & 14.4 & 20.0 & 20.1 & $18.8 \mathrm{~b}$ & $22.2 \mathrm{ab}$ & $26.7 \mathrm{a}$ & 44.4 & 56.4 & 57.9 & 24.9 & 26.4 & 27.8 \\
\hline 100 & $0.1 \mathrm{~b}$ & $2.8 \mathrm{~b}$ & $16.1 \mathrm{a}$ & $0.0 \mathrm{~b}$ & $2.5 \mathrm{~b}$ & $19.7 \mathrm{a}$ & $0.2 \mathrm{~b}$ & $3.6 \mathrm{~b}$ & $18.4 \mathrm{a}$ & $0.3 \mathrm{c}$ & $8.9 \mathrm{~b}$ & $54.1 \mathrm{a}$ & $4.1 \mathrm{~b}$ & $31.7 \mathrm{a}$ & $21.1 \mathrm{a}$ \\
\hline Sig. & $\mathrm{L}^{* *}$ & $\mathrm{Q}^{*}$ & NS & $\mathrm{L}^{* *}$ & $\mathrm{~L}^{* *}$ & NS & $\mathrm{Q}^{*}$ & $\mathrm{~L}^{* *}$ & $\mathrm{~L}^{*}$ & $\mathrm{~L}^{* *}$ & $\mathrm{~L}^{* *}$ & NS & $\mathrm{L}^{* *}$ & NS & NS \\
\hline \multicolumn{16}{|c|}{ Expt. 3} \\
\hline 0 & 48.7 & 49.4 & 55.0 & 60.0 & 55.2 & 55.0 & 22.6 & 24.4 & 20.4 & 131.3 & 129.0 & 130.4 & 33.0 & 30.4 & 36.5 \\
\hline 1 & 52.8 & 47.5 & 47.8 & 50.2 & 55.1 & 52.2 & 16.3 & 20.0 & 23.0 & 119.3 & 122.6 & 123.0 & 32.6 & 32.9 & 34.0 \\
\hline Sig. & $\mathrm{L}^{* *}$ & $\mathrm{Q}^{* *}$ & $\mathrm{~L}^{* *}$ & $\mathrm{Q}^{*}$ & $\mathrm{C}^{* * *}$ & $\mathrm{~L}^{* *}$ & $\mathrm{Q}^{* *}$ & $\mathrm{C}^{*}$ & $\mathrm{~L}^{* *}$ & $\mathrm{~L}^{* *}$ & $\mathrm{C}^{* *}$ & $\mathrm{~L}^{* *}$ & $\mathrm{~L}^{* *}$ & $\mathrm{Q}^{* *}$ & $\mathrm{C}^{* *}$ \\
\hline
\end{tabular}

${ }^{2}$ Mean separation within rows by Duncan's multiple range test $(P \leq 0.05)$.

Ns, *,***Nonsignificant and significant at $P \leq 0.05$ and $P \leq 0.01$, respectively, for linear (L), quadratic (Q), and cubic (C) effects. marketable fruit. Yields following postbloom applications at the same rates were lower than those following prebloom treatments, but were higher than yields obtained with glyphosate application at bloom.

Significant interaction also occurred between glyphosate rate and stage of development for yield of cull fruit in Expt. 3 $(P \leq 0.0001)$. Whereas cull fruit yield was reduced by prebloom and bloom applications of 60 and $100 \mathrm{~g} \cdot \mathrm{ha}^{-1}$, postbloom application increased cull yield to $72 \mathrm{t} \cdot \mathrm{ha}^{-1}$; this declined to $64 \mathrm{t} \cdot \mathrm{ha}^{-1}$ with a further increase in glyphosate rate to $100 \mathrm{~g} \cdot \mathrm{ha}^{-1}$. Yields with prebloom and bloom applications of 60 and $100 \mathrm{~g} \cdot \mathrm{ha}^{-1}$ glyphosate were similar and lower than the yield of cull fruit obtained with postbloom applications.

\section{Discussion}

Based on these results in Florida, glyphosate drift or other accidental exposure to 10 to 100 $\mathrm{g} \cdot \mathrm{ha}^{-1}$ that induces sublethal foliar injury and flower abscission can be expected to reduce marketable yields of fresh market tomatoes. The stage of reproductive development at which exposure occurred was critical. Exposure to 60 to $100 \mathrm{~g} \cdot \mathrm{ha}^{-1}$ during the period 4 to 5.5 weeks after transplanting, just prior to bloom of the first cluster and during bloom, caused foliar injury and flower abscission, and reduced fruit set. Plants treated later were larger and more mature. They were less susceptible to foliar injury and had already set some fruit, so there was a correspondingly lower impact on yield. Plants treated prebloom, but earlier than 4 weeks after transplanting, suffered considerable foliar injury at rates $>10$ $\mathrm{g} \cdot \mathrm{ha}^{-1}$; however, yields were not reduced as precipitously as were yields of plants treated at bloom. These plants were in the vegetative growth phase and thus not subject to the severe flower loss of plants treated just prior to or at 
bloom. Therefore, flower number may be a better indicator of the negative effects of sublethal glyphosate rates on tomato yield than is foliar injury.

That greatest yield reductions of fresh market tomatoes were associated with exposure to glyphosate at or near bloom is supported by the results of a similar study with processing tomatoes; yields of plants treated with 100 $\mathrm{g} \cdot \mathrm{ha}^{-1}$ glyphosate applied early in the season were reduced when compared with those of plants treated mid-season (Romanowski, 1980). In addition, in that study, yields were not affected by treatment late in the season. In the present study, flowers abscised at the higher rates of glyphosate used. Romanowki (1980) did not report flower abscission, but stated that some flowers on the glyphosate-treated plants were white, rather than yellow. Adverse effects of glyphosate applied during flowering have also been reported in pasture legumes. Rates of 90 and $162 \mathrm{~g} \cdot \mathrm{ha}^{-1}$ applied to subterranean clover (Trifolium subterraneum L.) and of $112 \mathrm{~g} \cdot \mathrm{ha}^{-1}$ to annual medic (Medicago polymorpha $\mathrm{L}$.) during early- to mid-flowering reduced seed yields (Wallace et al., 1998). For 'Sunny' a determinate tomato cultivar, sublethal glyphosate drift (equivalent to rates $>10$ $\mathrm{g} \cdot \mathrm{ha}^{-1}$ ) that results in excessive flower abscission could be detrimental to the crop. Marketable yield of indeterminate cultivars would probably be affected to a lesser degree because the plants would continue to flower as they outgrew the damage. However, profitability of the crop often depends on earliness of harvest and that advantage is lost when plants are exposed to glyphosate just prior to or at bloom. In addition, yields in these studies were so severely reduced by rates of 60 and $100 \mathrm{~g} \cdot \mathrm{ha}^{-1} \mathrm{glyphosate}$, applied at or near bloom, that producers of 'Sunny' who experience a similar degree of crop injury would be welladvised to abandon and plow under the crop.

\section{Literature Cited}

Atkinson, D. 1985. Glyphosate damage symptoms and the effects of drift, p. 455-465. In: E Grossbard and D. Atkinson (eds.). The herbicide glyphosate. Butterworths, London.

Cornish, P.S. 1992. Glyphosate residues in a sandy soil affect tomato transplants. Austral. J. Expt. Agr. 32:395-399.

Eberbach, P.L. and L.A. Douglas. 1983. Persistence of glyphosate in a sandy loam. Soil Biol. Biochem. 15:485-487.

Frans, R., R. Talbert, D. Marx, and H. Crowley. 1986. Experimental design and techniques for measuring and analyzing plant responses to weed control practices, p. 29-46. In: N.D. Camper (ed.). Research methods in weed science. Southern Weed Sci. Soc., Champaign, Ill.

Gilreath, J.P., C.A. Chase, and S.J. Locascio. 2000 Influence of sublethal glyphosate rates on leaf mineral content of tomato. HortScience. 35:1078-1082.
Mollenhauer, C., C.C. Smart, and N. Amrhein. 1987. Glyphosate toxicity in the shoot apical region of the tomato plant. 1. Plastid swelling is the initial ultrastructural feature following in vivo inhibition of 5-enolpyruvylshikimic acid 3phosphate synthase. Pest. Biochem. Physiol. 29:55-65.

Mueller, T.C. and A.R. Womac. 1997. Effect of formulation and nozzle type on droplet size with isopropylamine and trimesium salts of glyphosate. Weed Technol. 11:639-643.

Romanowski, R.R. 1980. Simulated drift studies with herbicides on field-grown tomato. HortScience 15:793-794.

Russo, V.M. 1990. Reaction of tomato cultivars to a sublethal dose of glyphosate. HortScience 25:1662.

Semidey, N. and L. Almodóver. 1987. Glyphosate on tomato and sweet pepper yields. J. Agr. Univ. Puerto Rico 71:235-237.

Singh, B.K. and D.L. Shaner. 1998. Rapid determination of glyphosate injury to plants and identification of glyphosate-resistant plants. Weed Technol. 12:527-530.

Snedecor, G.W. and W.G. Cochran. 1980. Statistical methods. The Iowa State Univ. Press, Ames.

Wallace, A., R.A. Lancaster, and N.L. Hill. 1998. Application of non-selective herbicides during flowering of pasture legumes can reduce seed yield and alter seed characteristics. Austral. J. Expt. Agr. 38:583-594.

Yates, W.E., N.B. Akesson, and D.E. Bayer. 1978. Drift of glyphosate sprays applied with aerial and ground equipment. Weed Sci. 26:597604. 